\title{
PEMETAAN POTENSI DAN PENYUSUNAN PAKET WISATA DI KABUPATEN BANGKA SELATAN
}

\author{
Titin Fatimah $^{1}$, Rode Ayu Wahyuningputri ${ }^{2}$, dan Revalino Tigor Hasudungan ${ }^{3}$ \\ ${ }^{1}$ Jurusan Arsitektur dan Perencanaan, Fakultas Teknik, Universitas Tarumanagara Jakarta \\ Surel: titinf@ft.untar.ac.id \\ ${ }^{2}$ Inspire Travel and Tourism Learning Center Jakarta \\ Surel: raputri.mails@yahoo.com \\ ${ }^{3}$ Akademi Pariwisata Indonesia Jakarta \\ Surel: linotobing@yahoo.com
}

\begin{abstract}
The Bangka Belitung Islands are known as one of the largest tin producers in Indonesia. Since the last few years, tin mining activities are no longer the primary economic source, but have shifted towards tourism. Especially since the introduction of the novel and movie Laskar Pelangi, making Belitung one of the most visited tourist destinations and affecting the number of visits to Bangka Island. So far, the center of tourism activities on Bangka Island only revolves around Sungailiat and its surroundings, not yet reaching South Bangka. Whereas in the South Bangka area there are also many exciting potentials to be developed. For this reason, it is necessary to develop a strategy so that South Bangka can also be developed into an alternative tourist destination other than Sungailiat. One of the methods used is mapping tourism potential and compiling travel patterns to become tour packages to be promoted. FGDs were conducted by involving tourism actors, professional associations, and the local Tourism Office. This community service activity is also a collaborative activity between the Deputy for Destination Development at the Ministry of Tourism of the Republic of Indonesia and the Tourism Office of the Province of Bangka Belitung. This activity resulted in the design of tour packages for the South Bangka area. There are two kinds of tour packages produced named 'Kelapan Snorkeling' and 'Bangka Energic Underwater'; both equipped with an itinerary map.
\end{abstract}

Keywords: tourism potentials, tour package, travel pattern, South Bangka

\begin{abstract}
ABSTRAK
Kepulauan Bangka Belitung selama ini dikenal sebagai salah satu penghasil timah terbesar di Indonesia. Sejak beberapa tahun terakhir, kegiatan penambangan timah bukan lagi menjadi sumber ekonomi utama, namun sudah bergeser ke arah pariwisata. Apalagi sejak dikenalnya novel dan film Laskar Pelangi, mejadikan Belitung sebagai salah satu destinasi wisata yang banyak dikunjungi, dan berpengaruh juga pada angka kunjungan ke Pulau Bangka. Selama ini pusat kegiatan wisata di Pulau Bangka hanya berkisar di Sungailiat dan sekitarnya, belum sampai merambah ke Bangka Selatan. Padahal di kawasan Bangka Selatan ini juga banyak potensi yang menarik untuk dikembangkan. Untuk itu perlu disusun strategi agar Bangka Selatan juga bisa dikebangkan menjadi destinasi wisata alternatif selain Sungailiat. Metode yang dipakai salah satunya dengan pemetaan potensi wisata dan penyusunan pola perjalanan hingga menjadi paket wisata untuk dipromosikan. FGD dilakukan dengan melibatkan para pelaku wisata, asosiasi profesi dan Dinas Pariwisata setempat. Kegiatan pengabdian kepada masyarakat kali ini sekaligus merupakan kegiatan kerjasama antara Deputi Bidang Pengembangan Destinasi Kementerian Pariwisata RI dan Dinas Pariwisata Provinsi Bangka Belitung. Kegiatan ini menghasilkan rancangan paket wisata ke kawasan Bangka Selatan. Paket wisata yang dihasilkan ada 2 macam yaitu 'Kelapan Snorkeling' dan 'Bangka Energic Underwater', dengan masing-masing dilengkapi dengan peta alur perjalanannya.
\end{abstract}

Kata Kunci: potensi wisata, paket wisata, pola perjalanan, Bangka Selatan

\section{PENDAHULUAN}

\section{Analisis Situasi}

Dalam sektor pariwisata, Pulau Bangka sedikit tertinggal dibandingkan dengan Pulau Belitung yang sudah maju. Pada tahun 2019, jumlah wisatawan di Pulau Bangka Belitung mencapai 
438,373 jiwa dan didominasi oleh wisatawan domestik. Perkembangan pariwisata di Pulau Belitung lebih dahulu berkembang, terutama setelah tren novel dan film Laskar Pelangi di tahun 2008. Momentum tersebut membawa dampak positif dengan makin bertambahnya wisatawan yang datang untuk menikmati keindahan alam Pulau Belitung (Megawandi, 2020). Maka tak heran untuk perkembangan pariwisatanya, Pulau Belitung jauh lebih maju dan tertata. Terlebih, Kabupaten Belitung masuk dalam Kawasan Strategis Pariwisata Nasional (KSPN) Tanjung Kelayang - Belitung dan sekitarnya, sehingga banyak mendapatkan dukungan program pengembangan dari Pemerintah Pusat (Ramadhani, 2018).

Pengembangan destinasi di Pulau Bangka relatif bagus, dan pelaku wisatanya juga sudah memiliki kesadaran yang cukup bagus. Di Pulau Bangka khususnya, kegiatan pariwisata masih belun merata di setiap daerah atau kabupaten. Saat ini kebanyakan kegiatan wisata terpusat di Sungailiat dan sekitarnya di Kabupaten Bangka serta Kota Pangkalpinang. Sedangkan Kabupaten Bangka Barat, Bangka Tengah dan Bangka Selatan belum dikembangkan secara maksimal.

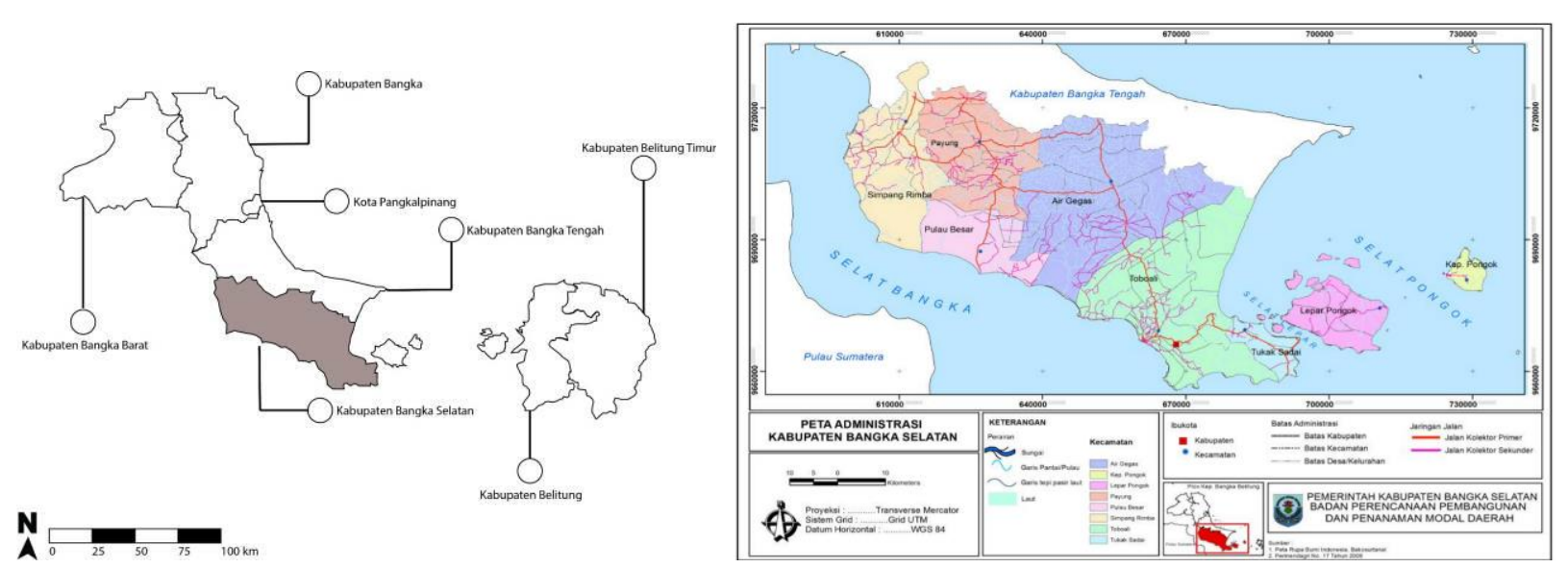

Gambar 1. a. Peta lokasi, b. Peta Administrasi Kabupaten Bangka Selatan

(Sumber: a. Digambar oleh Penulis, 2021, b. Bappeda Bangka Selatan)

Kabupaten Bangka Selatan merupakan salah satu Kabupaten di Provinsi Kepulauan Bangka Belitung yang terletak di bagian paling selatan Pulau Bangka sehingga Bangka Selatan memiliki banyak daerah pesisir pantai dan pulau-pulau kecil yang tersebar di beberapa wilayah kecamatan. Oleh karena itu Bangka Selatan memiliki banyak pesona keindahan alam, hamparan pantai yang menawan dan keunikan adat instiadat budaya daerah. Bangka selatan memiliki total luas $3.607,08 \mathrm{~km}^{2}$ dengan relief wilayah mulai dari daratan, pulau kecil dan bukit yang berkisar antara 0 - 500 meter di atas permukaan laut. Wilayah Kabupaten Bangka Selatan berbatasan dengan kabupaten Bangka Tengah di sebelah utara, Selat Bangka dan Laut Jawa di sebelah barat dan selatan, dan Selat Gaspar di sebelah timur. Kabupaten ini terdiri atas 8 kecamatan yaitu Toboali, Payung, Simpang Rimba, Air Gegas, Sadai, Pulau Besar, Lepar Pongok dan Kepulauan Pongok.

Kabupaten Bangka Selatan memiliki berbagai macam potensi wisata yang menjadi daya tarik tersendiri bagi wisatawan. Ada 6 kategori wisata yang ada di Kabupaten Bangka Selatan yaitu Wisata Alam, Wisata Budaya, Wisata Jelajah Pulau, Wisata Pantai, Wisata Perbukitan dan Wisata Sejarah.Jumlah penduduk Kabupaten Bangka Selatan mencapai 198.189 jiwa pada tahun 2021 dengan rincian 102.447 jiwa Laki-Laki dan 95.742 jiwa Perempuan dengan kepadatan penduduk 55 jiwa/km2 (BPS Kabupaten Bangka Selatan, 2021). Melayu merupakan suku asli di Kabupaten Bangka Selatan selain itu terdapat juga suku ras seperti Tionghoa, Jawa, Bugis, 
Madura, serta lainnya. Mereka telah hidup berdampingan selama bertahun-tahun. Bahasa utama yang digunakan oleh masyarakat dalam kehidupan sehari-hari adalah bahasa Melayu kemudian Bahasa Indonesia dan bahasa suku lain dalam lingkup yang lebih kecil.

Kabupaten Bangka Selatan adalah salah satu sentra penghasil beras di Provinsi Bangka Belitung yang juga dikenal sebagai daerah penghasil perkebunan seperti karet, lada dan kelapa sawit yang tersebar hampir di seluruh wilayahnya. Sebagai daerah yang terletak paling selatan atau di bagian paling bawah peta Pulau Bangka wilayah lautnya cukup luas sehingga Bangka Selatan juga kaya akan hasil laut dan potensi kawasan wisata bahari. Toboali adalah ibu kota kabupaten Kabupaten Bangka Selatan berjarak sekitar 125 km dari Pangkalpinang, ibukota Provinsi Bangka Belitung. Toboali telah menjadi daerah penting yang dibuktikan dengan adanya benteng di kota ini yang dibangun sekitar tahun 1825 . Toboali dulunya adalah pelabuhan dan salah satu basis pertahanan pemerintah kolonial Belanda. Perannya sebagai kota penting di Bangka Selatan berlanjut hingga saat ini yaitu sebagai pusat pemerintahan dan ekonomi (TIC Bangka Selatan, 2021).

\section{Permasalahan}

Pengembangan destinasi di Pulau Bangka relatif bagus, namun kegiatan pariwisata masih belum merata di setiap daerah atau kabupaten (kebanyakan terpusat di Sungailiat dan sekitarnya di Kabupaten Bangka serta Kota Pangkalpinang). Sedangkan Kabupaten Bangka Barat, Bangka Tengah dan Bangka Selatan belum dikembangkan secara maksimal. Padahal UU No. 10 Tahun 2009 tentang Kepariwisataan sudah jelas menyebutkan bahwa pembangunan kepariwisataan diperlukan untuk mendorong pemerataan kesempatan berusaha dan memperoleh manfaat, serta mampu menghadapi tantangan perubahan kehidupan baik tingkat lokal, nasional, hingga global. Wilayah Kabupaten Bangka Selatan yang terletak di ujung selatan dan berjarak agar jauh dari Kota Pangkalpinang menyebabkan akses jangkauannya agak terbatas. Untuk itu perlu digencarkan pembuatan paket-paket wisata yang akan mempermudah wisatawan mengunjungi berbagai daya tarik wisata di Kabupaten Bangka Belitung.

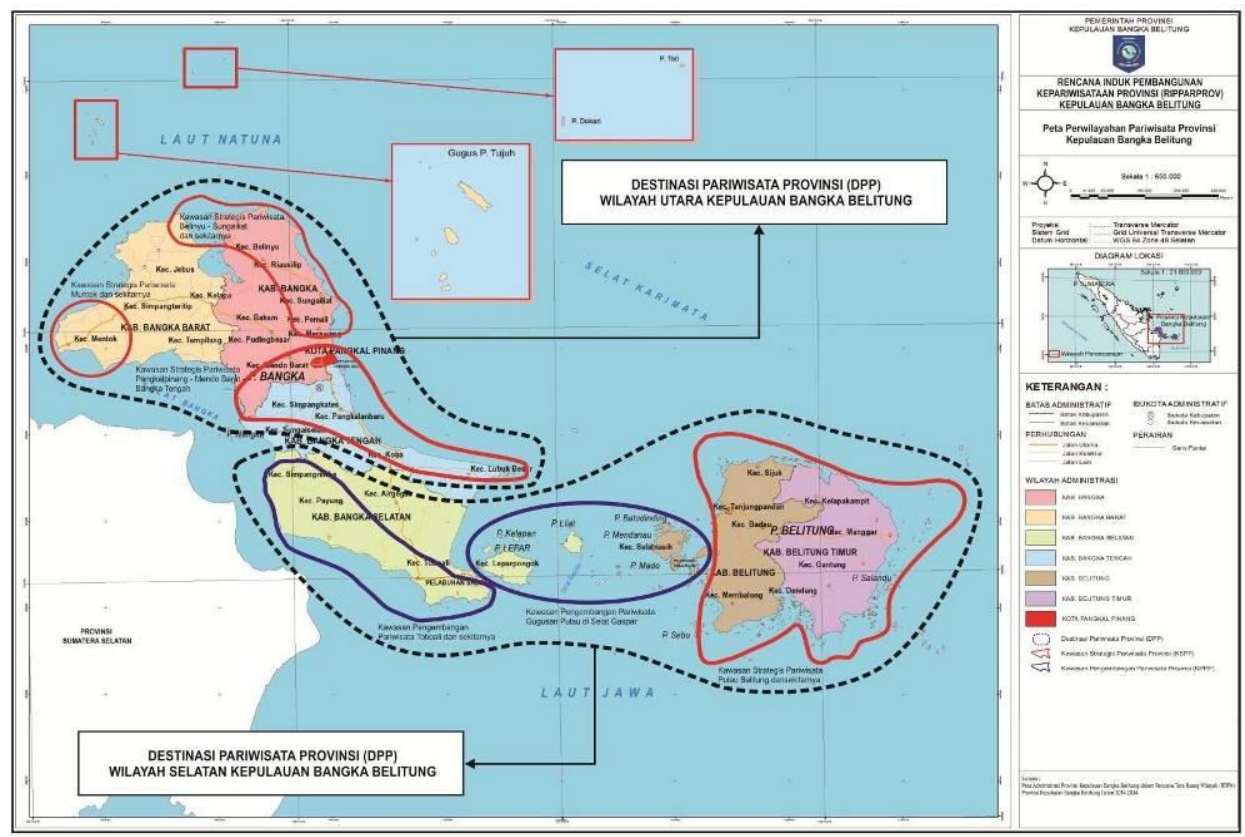

Gambar 2. Peta Perwilayahan Pariwisata Provinsi Kepulauan Bangka Belitung

(Sumber: Rencana Induk Pembangunan Kepariwisataan Provinsi (RIPPARPROV) Kepulauan Bangka Belitung 2016 - 2025) 


\section{Solusi Mitra}

Untuk mengatasi permasalahan yang disebutkan di atas, perlu dilakukan pemetaan potensi wisata yang dimiliki di Kabupaten Bangka Selatan, terutama untuk bidang alam, sejarah dah budaya. Idealnya dilakukan pemetaan budaya untuk mengetahui potensi yang dimiliki secara lebih mendalam (Fatimah et al., 2018), namun karena keterbatasan waktu, pemetaan bisa dilakukan dengan penelusuran melalui studi literatur. Kabupaten Bangka Selatan memiliki garis pantai yang cukup Panjang, sehingga potensi pariwisata alam cukup potensial untuk dikelola dan dikembangkan.

Ada beberapa kebijakan pembangunan daerah Kabupaten Bangka Selatan yang mengatur hal ini, di antaranya adalah Peraturan Daerah Nomor 7 Tahun 2016 tentang Rencana Induk Pembangunan Kepariwisataan Provinsi Kepulauan Bangka Belitung Tahun 2016-2025, Peraturan Daerah Nomor 6 Tahun 2012 tentang Rencana Pembangunan Jangka Panjang Daerah (RPJPD) Kabupaten Bangka Selatan Tahun 2005-2025, Peraturan Daerah Nomor 12 Tahun 2016 tentang Rencana Pembangunan Jangka Menengah Daerah (RPJMD) Kabupaten Bangka Selatan Tahun 2016-2021, Kebijakan pengembangan kepariwisataan di Kabupaten Bangka Selatan telah tercantum dalam kebijakan Rencana Tata Ruang Wilayah (RTRW) Kabupaten Bangka Selatan Tahun 2011-2031.

Berdasarkan beberapa kebijakan tersebut, dapat dilihat bahwa sektor pariwisata menjadi salah satu sektor prioritas untuk selalu dikembangkan dalam program-program pembangunan daerah. Menurut Kebijakan pengembangan pariwisata Kabupaten Bangka Selatan yang tercantum dalam RIPPDA Provinsi Kepulauan Bangka Belitung, salah satu objek wisata yang menjadi andalan Bangka Selatan adalah Kawasan Wisata Alam Bahari-Selat Lepar. Ini adalah kawasan wisata alam bahari pulau-pulau kecil yang merupakan tema utama pengembangan wisata kawasan Selat Lepar, yang sangat mendukung tema pariwisata provinsi (Nasrullah, 2021).

Dengan demikian penting untuk mengembangkan daya tarik Pantai Tanjung Kerasak dan Pulau Lepar maupun pulau-pulau kecil lainnya. Hal ini sejalan dengan kebijakan Pemerintah Indonesia yang saat ini sedang mengarahkan fokusnya pada pengembangan pulau-pulau kecil sebagai kawasan konservasi bersama dengan industri pariwisata (Kurniawan, 2016). Selanjutnya perlu digali lebih lanjut untuk pengolahan dan pengemasannya menjadi sebuah produk pariwisata yang menarik bagi wisatawan. Kegiatan ini bermaksud menyusun paket wisata dengan menggabungkan antara perjalanan wisata pulau, alam, sejarah dan budaya setempat dengan potensi dan daya tarik wisata yang sudah ada saat ini di Kabupaten Bangka Selatan.

\section{METODE PELAKSANAAN PKM}

Kegiatan PKM (Pengabdian Kepada Masyarakat) ini merupakan kegiatan kerjasama antara Asisten Deputi Pengembangan Wisata Budaya, Deputi Bidang Pengembangan Destinasi Pariwisata Kementerian Pariwisata RI, dan Dinas Pariwisata Provinsi Bangka Belitung. Penulis dalam hal ini berperan sebagai fasilitator, sekaligus mewakili Tim Percepatan Pengembangan Wisata Sejarah Religi Tradisi dan Seni Budaya.

Langkah-langkah yang dilakukan dalam pelaksanaan program ini adalah:

- Penelusuran dokumen literatur mengenai potensi dan profil wisata Kabupaten Bangka Selatan

- Penelusuran dokumen literatur mengenai Sejarah Kabupaten Bangka Selatan

- Melakukan Focus Group Discussion (FGD) tentang pengemasan produk wisata yang dikemas dalam bentuk Bimbingan Teknis Pengemasan Produk Wisata yang berlangsung di hotel Bangka City Kota Pangkalpinang pada tanggal 1-2 April 2019.

- Penyusunan Paket Wisata Bangka Selatan 


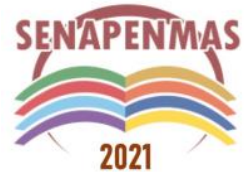

2021
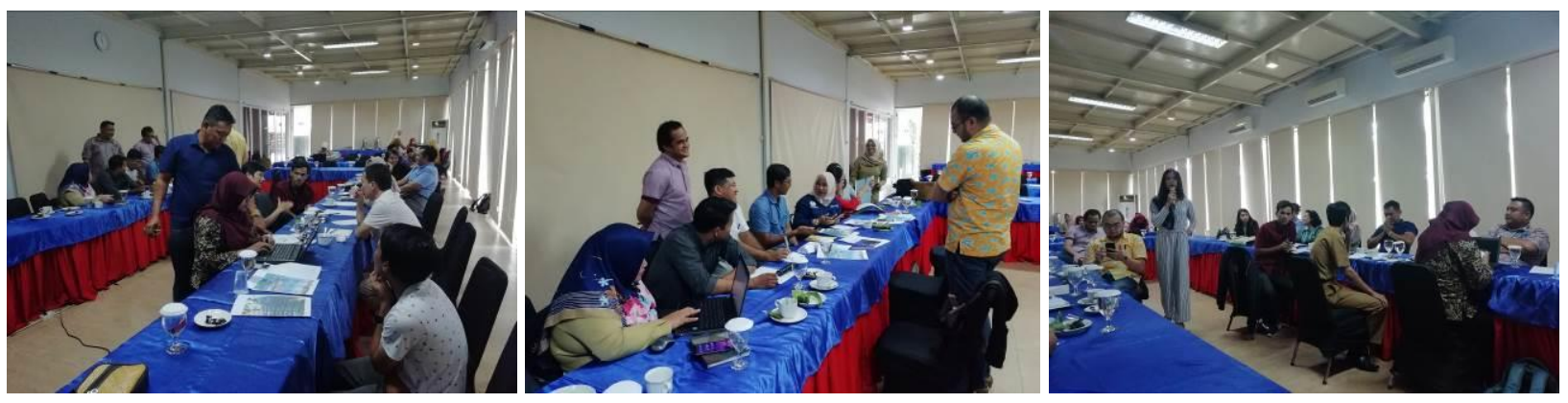

Gambar 3. Suasana Forum Group Discussion dengan para pelaku wisata

dan pemerintah setempat

(Sumber: Dokumentasi pribadi, 2019)

\section{HASIL DAN PEMBAHASAN}

\section{Profil Pariwisata Kabupaten Bangka Selatan}

Kabupaten Bangka Selatan memiliki potensi pariwisata yang cukup besar, terutama kondisi alam yang eksotis, ditambah dengan adat istiadat dan budaya yang cukup mengakar di dalam masyarakat. Ada 6 kategori wisata yang ada di Kabupaten Bangka Selatan yaitu Wisata Alam, Wisata Budaya, Wisata Jelajah Pulau, Wisata Pantai, Wisata Perbukitan dan Wisata Sejarah.

Sebagai kabupaten yang terkenal dengan wisata pantai yang mempesona, Kawasan Pantai di Kabupaten Bangka Selatan menjadi obyek wisata bahari. Hal ini didukung oleh Peraturan Daerah Nomor 17 Tahun 2007 tentang Penetapan Kawasan Wisata Bahari di bawah pengelolaan Dinas Pariwisata, Kebudayaan Pemuda dan Olahraga Kabupaten Bangka Selatan. Beberapa kegiatan di kawasan pantai yang dapat dilakukan dalam wisata pantai ini antara lain meliputi berenang, diving, snorkeling, jogging, memancing, dan wahana permainan air lainnya.

Pemerintah Kabupaten Bangka Selatan memberikan perhatian yang cukup besar antara lain dengan penyediaan beberapa fasilitas dan infrastruktur yang dapat menunjang kawasan ini sebagai obyek wisata unggulan. Untuk melihat profil pariwisata secara keseluruhan, perlu ditinjau dari Prinsip 3A (Atraksi-Aksesibilitas-Amenitas). Atraksi berarti daya tarik wisatanya, Akesibilitas menilai keterjangkauan yang biasanya dilihat dari moda transportasi menuju ke lokasi, sedangkan Amenitas meliputi kelengkapan fasilitas pendukung pariwisata.

a) Atraksi

Kabupaten Bangka Selatan memiliki potensi pariwisata yang cukup beragam yang terdiri dari Wisata Alam, Wisata Sejarah, Wisata Budaya, Wisata Jejalah Pulau, Wisata Jelajah Pantai, Wisata Perbukitan (lihat tabel 1). Berdasarkan data dari Dinas Pariwisata, Pemuda dan Olahraga Kabupaten Bangka Selatan, terdapat 618.000 orang wisatawan lokal maupun luar daerah yang datang berkunjung ke daerah tersebut sepanjang tahun 2018. Hal ini menunjukkan angka kunjungan wisatawan ke destinasi wisata yang ada di Bangka Selatan mengalami peningkatan satu hingga dua persen jika dibandingkan dengan angka kunjungan pada tahun 2017 yang hanya mencapai 610.000 orang. Destinasi wisata unggulan yang sering dikunjungi para wisatawan antara lain adalah Hutan Manggrove Desa Tukak, Pantai Tanjung Kerasak, Toboali dan Pulau Kelapan yang merupakan wisata alam dan wisata pulau (Lihat Gambar 4). 
Tabel 1. Daya Tarik Wisata Kabupaten Bangka Selatan

\begin{tabular}{|c|c|c|c|}
\hline No & Kategori & Daya Tarik Wisata & Peta Lokasi \\
\hline 1 & Wisata Alam & $\begin{array}{l}\text { 1. Bendungan Metukul } \\
\text { 2. Sungai Jeriji } \\
\text { 3. Air Terjun Penyaber } \\
\text { 4. Bendungan Bidadari } \\
\text { 5. Hutan Mangrove Desa Tukak } \\
\text { 6. Sumber Air Panas Nyelanding } \\
\text { 7. Batu Belimbing }\end{array}$ & \\
\hline 2 & Wisata Budaya & $\begin{array}{l}\text { 1. Ngarak Telok Serujo } \\
\text { 2. Sedekah Bumi } \\
\text { 3. Ritual Adat Buang Jung } \\
\text { 4. Kawin Massal Desa Serdang }\end{array}$ & \\
\hline
\end{tabular}

$\begin{array}{ll}3 \text { Wisata Jelajah Pulau } & \text { 1. Pulau Salma } \\ \text { 2. Pulau Tinggi } \\ \text { 3. Pulau Salah Nama } \\ \text { 4. Pulau Kelapan }\end{array}$

\begin{aligned} \hline Wisata Pantai & 1. Pantai Tanjung Labun \\ & 2. Pantai Lampu \\ & 3. Pantai Belawang \\ & 4. Pantai Nek Aji \\ & 5. Pantai Batu Perahu \\ & 6. Pantai Kelisut \\ & 7. Pantai Batu Kapur \\ & 8. Pantai Tanjung Kerasak \end{aligned}

\begin{tabular}{ll}
\hline 5 Wisata Perbukitan & 1. Bukit Nenek \\
& 2. Bukit Gebang
\end{tabular}

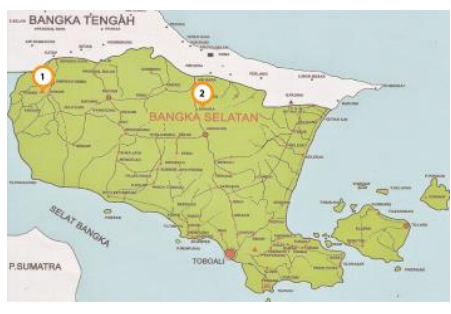

\begin{tabular}{ll}
\hline Wisata Sejarah & 1. Benteng Penutuk \\
& 2. Mercusuar Pulau Besar \\
& 3. Klenteng Dewi Sin Mu \\
4. Benteng Toboali
\end{tabular}

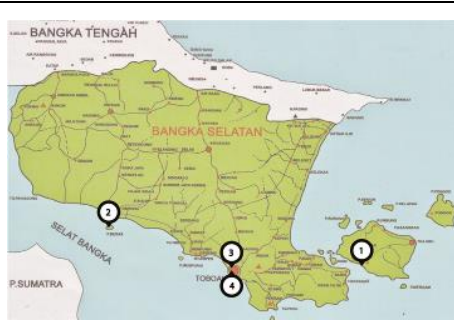

Sumber: Diolah dari https://www.wisatabangkaselatan.com/wisata, TIC Bangka Selatan, 2021 


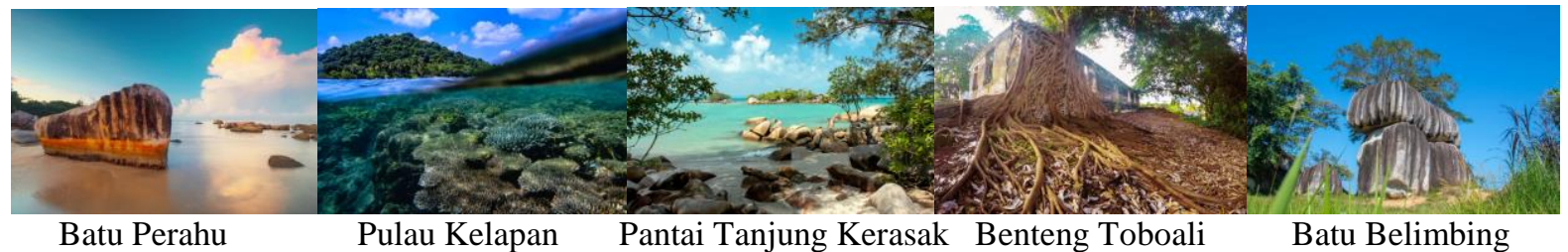

Gambar 4. Beberapa daya tarik wisata utama di Bangka Selatan

(Sumber: Dokumentasi TIC Bangka Selatan, 2021)
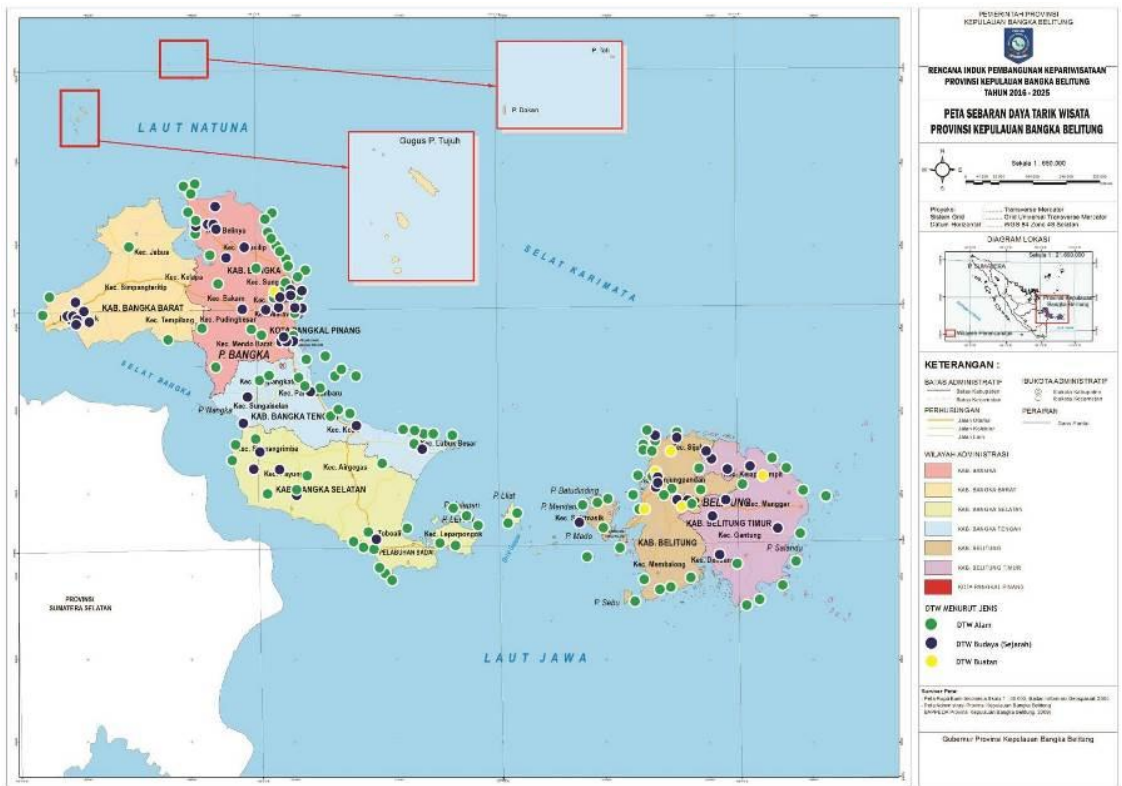

Gambar 5. Peta Sebaran Daya Tarik Wisata Provinsi Kepulauan Bangka Belitung (Sumber: Rencana Induk Pembangunan Kepariwisataan Provinsi (RIPPARPROV) Kepulauan Bangka Belitung 2016 - 2025)

b) Aksesibilitas

Jumlah wisatawan dari tahun ke tahun yang datang ke Bangka Belitung sangat fluktuatif. Dengan memiliki potensi wisata yang besar seharusnya kunjungan wisata dapat ditingkatkan. Namun pada kenyataanya angka kunjungan wisatawan ke Kabupaten Bangka Selatan belum sebanding jika dibandingkan dengan daya tarik yang ada. Hal ini dapat disebabkan antara lain karena pembangunan sejumlah infrastruktur dan sarana prasarana kepariwisatan yang belum merata di setiap destinasi wisata.

Banyaknya wisatawan yang berkunjung ke Kabupaten Bangka Selatan tidak diimbangi dengan pengembangan infrastruktur sistem transportasi yang memadai. Wisatawan yang datang ke Kabupaten Bangka Selatan pada umumnya merasa kesulitan mengakses angkutan umum yang murah, cepat, dan nyaman. Jumlah angkutan umum yang tersedia masih sangat terbatas dengan trayek yang juga masih terbatas. Kondisi ini tentu saja sangat tidak ideal bagi perkembangan kepariwisataan di Kabupaten Bangka Selatan ke depan.

Dilihat dari keterjangkauan, Kabupaten Bangka Selatan memiliki aksesibilitas yang kurang baik. Kabupaten Bangka Selatan yang dapat dijangkau dengan perjalanan udara menuju Bandar Udara Depati Amir yang terletak di Pangkalpinang, Kabupaten Bangka Tengah, dari Pangkalpinang perlu perjalanan sejauh $125 \mathrm{~km}$ selama 2 jam 15 menit mengunakan mobil 
atau travel Pangkalpinang - Toboali. Untuk menuju destinasi wisata dari toboali, wisatawan dapat menyewa kendaraan dari rental setempat.

\section{c) Amenitas}

Destinasi pariwisata perlu dilengkap dengan fasilitas pendukung, antara lain fasilitas akomodasi seperti hotel, homestay, restoran, dll. Terdapat 4 penginapan dan 3 homestay di Toboali dan 1 homestay di Tukak Sakai yang dapat digunakan wisatawan untuk menginap saat berlibur di kawasan Bangka Selatan. Fasilitas akomodasi ini memegang peranan penting dalam memenuhi kebutuhan wisatawan yang datang, karena jarak yang jauh menuntut mereka untuk menginap. Selain itu juga terdapat 3 agen perjalanan lokal yang dapat membantu dan memandu wisatawan dalam menjelajahi destinasi wisata di Kabupaten Bangka Selatan.

\section{Potensi Pengembangan Kawasan Pariwisata di Bangka Selatan}

Dalam RIPPARPROV Bangka Belitung tahun 2016-2025, Kabupaten Bangka Selatan dinyatakan sebagai sebagai pusat pelayanan sekunder pariwisata daerah (bersama dengan Muntok, Sungailiat, Toboali, dan Pulau Mendanau); Kota Pangkalpinang dan Tanjungpandan sebagai pusat pelayanan primer pariwisata. Selain itu, Kawasan Pengembangan Pariwisata Provinsi (KPPP) Toboali dan sekitarnya, KPPP Gugusan Pulau di Selat Gaspar diarahkan untuk membentuk citra sebagai destinasi pariwisata bahari dan budaya khas, meningkatkan daya saing produk pariwisata tingkat internasional, menciptakan pembangunan terpadu serta penyebaran perkembangan pariwisata yang lebih luas. Pemkab Bangka Selatan sudah berupaya untuk menggalakkan pembangunan sarana prasana untuk mendukung pengembangan pulau-pulau kecil sebagai salah satu destinasi unggulan (Putra, 2018).

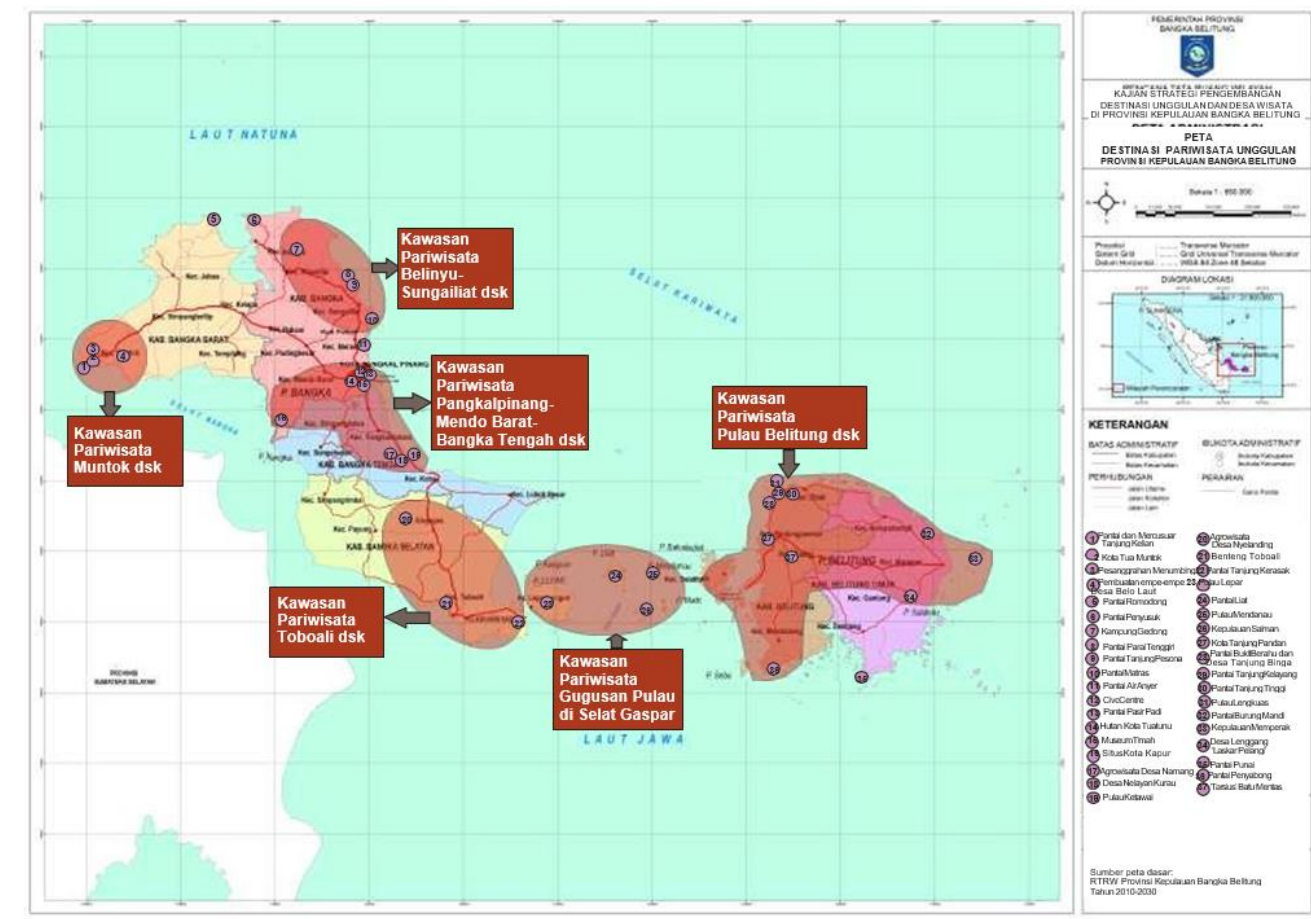

Gambar 6. Peta Sebaran Destinasi Pariwisata Unggulan Provinsi Kepulauan Bangka Belitung (Sumber: BAPPEDA Provinsi Kepulauan Bangka Belitung, 2013) 


\section{Penyusunan Paket Wisata Kabupaten Bangka Selatan}

Mengingat akses di Bangka Selatan yang cukup sulit, maka penyusunan paket wisata menjadi sangat penting. Paket wisata adalah kombinasi atau gabungan dari komponen-komponen pariwisata yang terdiri dari transportasi, akomodasi, atraksi wisata, dan makanan, yang dilengkapi dengan jasa Tour Leader yang dijual kepada wisatawan dalam satu harga tertentu. Hal ini untuk mempermudah wisatawan dan menikmati perjalanan wisatanya, karena semuanya sudah diatur oleh Biro Perjalanan Wisata (Holloway \& Humphreys, 2016).

Menurut Nuriata (2014:15) paket wisata (tour package) adalah suatu perjalanan wisata dengan satu atau beberapa motif kunjungan yang menggabungkan beberapa fasilitas perjalanan tertentu dalam sebuah acara perjalanan, yang menyangkut seluruh komponen dari perjalanan wisata, dan dijual dalam harga tertentu.

Paket wisata juga dapat dianggap sebagai sebuah sistem, yakni sebuah tatanan yang terdiri atas unsur-unsur penyusun yang saling berkaitan yaitu wisatawan, atraksi, fasilitas, dan waktu. Untuk membuat suatu paket wisata yang baik, keempat komponen tersebut harus dipahami betul-betul dan tersedia informasi yang cukup sebagai landasan dalam penyusunan paket wisatanya.

Penyusunan paket wisata harus mempertimbangkan daya tarik wisata yang akan diangkat menjadi tema utamanya. Namun begitu, dalam penyusunannya bisa menggabungkan beberapa jenis daya tarik sekaligus untuk bisa melengkapi. Misalnya, daya yarik utama adalah wisata pantai dan pulau, namun dalam pola perjalanannya bisa memasukkan daya tarik wisata sejarah dan budaya setempat (Prasetyo, 2017; Fatimah, 2020).

Pelaksanaan kegiatan PKM (Pengabdian Kepada Masyarakat) dikemas dalam kegiatan Bimtek (Bimbingan Teknis) dengan format Focus Group Discussion (FGD). Kegiatan ini dilakukan bersama dengan para pelaku wisata di Pulau Bangka. Para peserta diberi pembekalan terlebih dahulu mengenai konsep-konsep dasar dalam penyusunan paket wisata, termasuk menentukan pola perjalanan untuk menyusun peta jelajah yang wisatanya (Fatimah \& Ariaji, 2018). Setelah itu peserta yang hadir dibagi menjadi 2 kelompok besar untuk berdiskusi menyusun paket wisata usulan masing-masing. Berikut ini adalah paket wisata yang dihasilkan dari kegiatan. Ada 2 paket wisata dengan tema 'Kelapan Snorkeling' (4 Hari 3 Malam) dan 'Bangka Energic Underwater' (3 Hari 2 Malam).

\section{Tabel 2. Paket Wisata 1 - Kelapan Snorkeling - Hari Pertama}

\begin{tabular}{lll}
\hline No & Waktu & Acara \\
\hline 1. & $08.00-08.30$ & Hotel di Pangkalpinang \\
\hline 2. & $08.30-09.30$ & Namang \\
\hline 3. & $10.30-11.00$ & $\begin{array}{l}\text { Kaolin dan Sumur } \\
\text { Tujuh }\end{array}$ \\
\hline 4. & $11.00-11.30$ & Bikang \\
\hline 5. & $12.30-13.00$ & Makan Siang di Toboali \\
\hline 6. & $13.00-13.30$ & Benteng Toboali \\
\hline 7. & $13.30-13.45$ & Klenteng Dewi SinMu \\
\hline 8. & $14.45-18.00$ & $\begin{array}{l}\text { Kawasan Wisata Pesisir } \\
\text { Tanjung Ketapang } \\
\text { (Batu Belimbing- Pantai }\end{array}$ \\
& & $\begin{array}{l}\text { Kelisut- Batu perahu- } \\
\text { Batu Kapur-Batu } \\
\text { Kodok) }\end{array}$ \\
\hline 9. & $18.00-20.00$ & Makan Malam \\
\hline 10. & 20.00 & Free Time \\
\hline
\end{tabular}

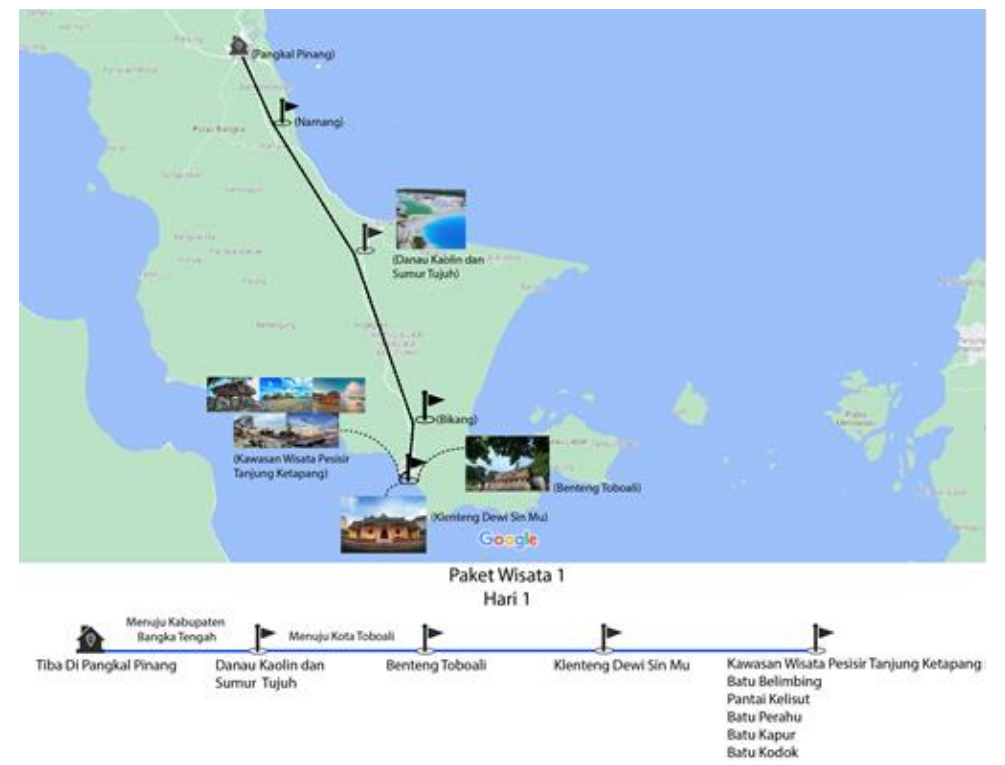


Tabel 3. Paket Wisata 1 - Kelapan Snorkeling - Hari Kedua

\begin{tabular}{lll}
\hline No & Waktu & Acara \\
\hline 1. & 06.00 & $\begin{array}{l}\text { Berangkat dari Hotel ke } \\
\text { Tukak }\end{array}$ \\
\hline 2. & $07.00-07.30$ & Sarapan di Tukak \\
\hline 3. & $07.30-09.00$ & Tukak -Kelapan \\
\hline 4. & $09.00-11.00$ & Snorkeling di Kelapan \\
\hline 5. & $11.00-11.30$ & Pulau Salah Nama \\
\hline 6. & $11.30-12.30$ & Pulau Tinggi \\
\hline 7. & $12.30-13.30$ & $\begin{array}{l}\text { Makan Siang di } \\
\text { Keramba Pulau Tinggi }\end{array}$ \\
\hline 8. & $13.30-14.00$ & Menuju ke Tukak \\
\hline 9. & $14.00-15.00$ & Susur Sungai Banteng \\
\hline 10. & $15.00-16.00$ & Jelajah Mangrove dan \\
& & $\begin{array}{l}\text { Kerajinan Daur Ulang } \\
\text { Tukak }\end{array}$ \\
\hline 11. & $16.00-17.00$ & Tukak-Toboali \\
\hline 12. & $17.00-19.00$ & Free time \\
\hline 13. & $19.00-20.00$ & Makan Malam \\
\hline & &
\end{tabular}

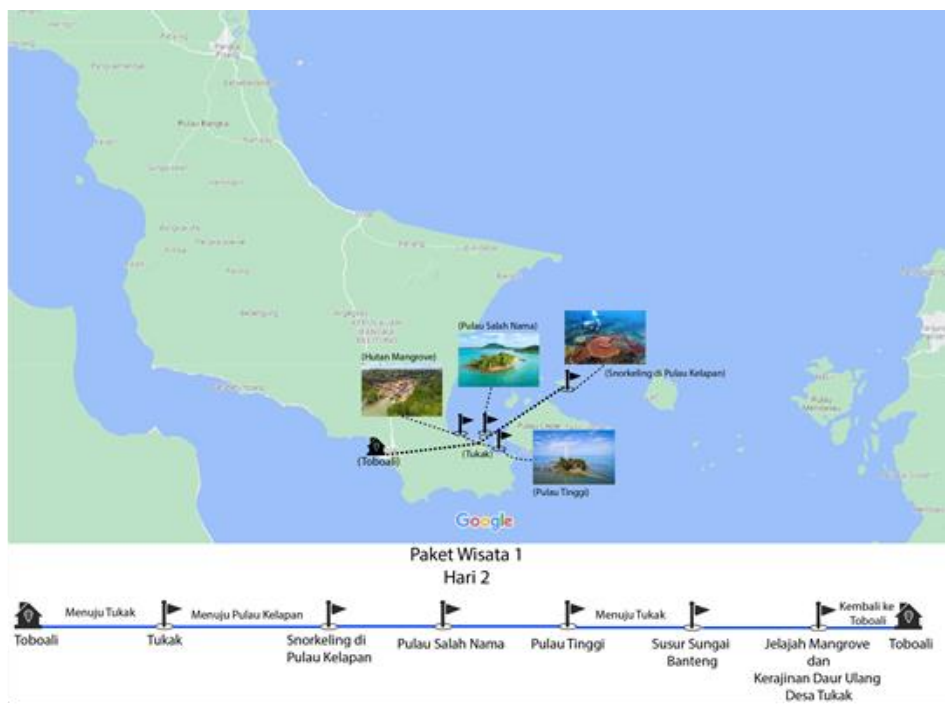

Tabel 4. Paket Wisata 1 - Kelapan Snorkeling - Hari Ketiga

\begin{tabular}{lll}
\hline No & Waktu & Acara \\
\hline 1. & $08.00-08.30$ & Check Out Hotel \\
\hline 2. & $08.30-10.00$ & $\begin{array}{l}\text { Mengunjungi Proses } \\
\text { Pembuatan Terasi dan } \\
\text { Kemplang panggang }\end{array}$ \\
\hline 3. & $10.00-12.00$ & Toboali-Kurau \\
\hline 4. & $12.00-14.00$ & Makan Siang \\
\hline 5. & $14.00-15.00$ & Jembatan Emas \\
\hline 6. & $15.00-16.00$ & $\begin{array}{l}\text { Bangka Botanical } \\
\text { Garden }\end{array}$ \\
\hline 7. & $16.00-17.00$ & Pasir Padi \\
\hline 8. & $17.00-19.00$ & $\begin{array}{l}\text { Check in Hotel } \\
\text { Free Time }\end{array}$ \\
\hline 9. & $19.00-20.00$ & Makan Malam \\
\hline 10. & 20.00 & Free Time \\
\hline
\end{tabular}

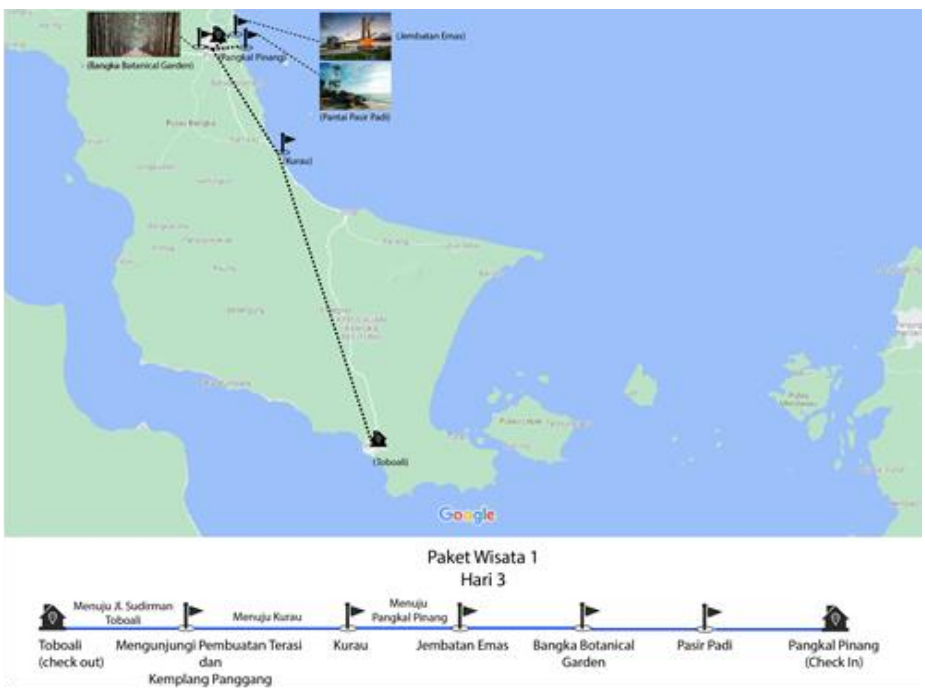

Tabel 5. Paket Wisata 1 - Kelapan Snorkeling - Hari Keempat

\begin{tabular}{lll}
\hline No & Waktu & Acara \\
\hline 1. & $08.00-18.15$ & Check Out Hotel \\
\hline 2. & $08.15-09.00$ & Museum Timah \\
\hline 3. & $09.00-10.00$ & Toko Oleh-Oleh \\
\hline 4. & 10.00 & Tranfer Ke Bandara \\
\hline
\end{tabular}

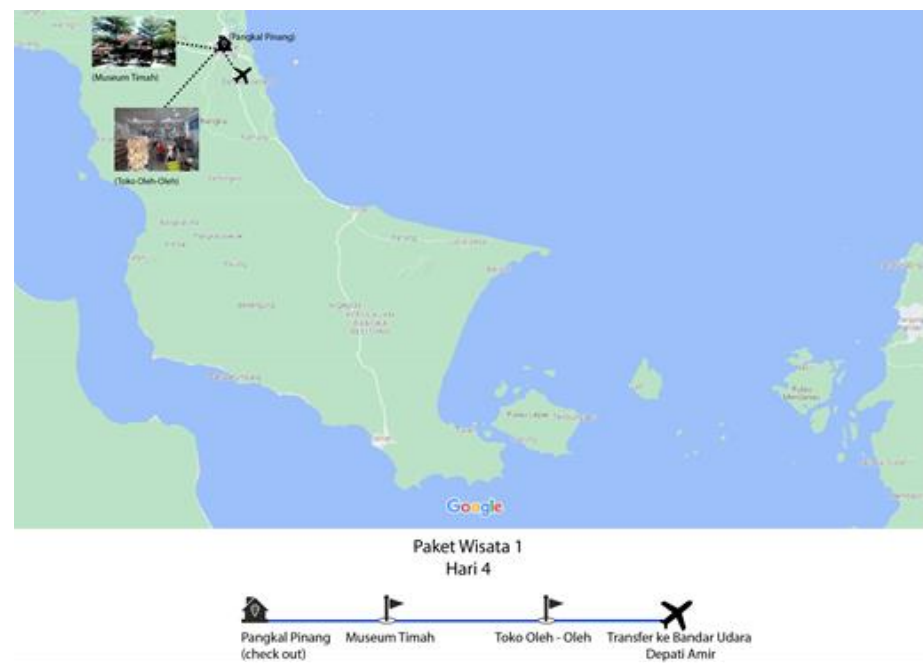




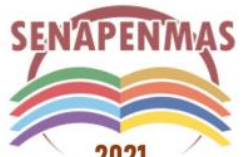

2021
Seminar Nasional Hasil Penelitian dan Pengabdian Kepada Masyarakat 2021

Pengembangan Ekonomi Bangsa Melalui Inovasi Digital Hasil Penelitian dan Pengabdian Kepada Masyarakat Jakarta, 21 Oktober 2021

Paket Wisata 1 'Kelapan Snorkeling' ini mengambil destinasi wisata Kelapan di Bangka Selatan sebagai daya tarik utama, yang terkenal dengan wilayah pantai dan keindahan alam bawah lautnya. Snorkeling menjadi pilihan kegiatan yang tepat untuk menikmati keindahan yang ada di Kelapan. Namun demikian, sebagai sebuah paket wisata yang lengkap, selama 4 hari 3 malam wisatawan disuguhkan beragam daya tarik wisata dari sejak di Kota Pangkalpinang, hingga ke berbagai wilayan di Bangka Selatan.

Tabel 6. Paket Wisata 2 - Bangka Energic Underwater - Hari Kesatu

\begin{tabular}{|c|c|}
\hline No Waktu & Acara \\
\hline 1. 07.45 & Tiba di bandara depati amir \\
\hline 2. $07.45-08.15$ & Proses bagasi \\
\hline 3. $\quad 08.15-08.30$ & Bertemu team, penjemputan \\
\hline 4. $\quad 08.30-09.30$ & Diajak mencicipi mie koba \\
\hline $\begin{array}{lr}5 . & 09.30-09.40 \\
\end{array}$ & Menuju museum timah \\
\hline $\begin{array}{ll}6 . & 09.40-11.40\end{array}$ & $\begin{array}{l}\text { City tour (pownis) } \\
\text { pangkalpinang }\end{array}$ \\
\hline 7. $11.40-12.00$ & Menuju resto (gale-gale) \\
\hline $\begin{array}{ll}8 . & 12.00-13.00\end{array}$ & $\begin{array}{l}\text { Makan siang di resto (gale- } \\
\text { gale) }\end{array}$ \\
\hline $\begin{array}{ll}9 . & 13.00-14.00\end{array}$ & $\begin{array}{l}\text { Perjalanan ke danau } \\
\text { kaolin/danau biru }\end{array}$ \\
\hline 10. $14.00-14.30$ & $\begin{array}{l}\text { Photo stop danau kaolin/danau } \\
\text { biru }\end{array}$ \\
\hline 11. $14.30-15.30$ & $\begin{array}{l}\text { Perjalanan ke Bangka Selatan } \\
\text { (Toboali) }\end{array}$ \\
\hline 12. $15.30-15.45$ & $\begin{array}{l}\text { TIC (Toboali Information } \\
\text { Center) }\end{array}$ \\
\hline 13. $15.45-16.15$ & $\begin{array}{l}\text { Benteng Toboali - kelenteng } \\
\text { Dewi Sin Mu }\end{array}$ \\
\hline 14. $16.15-16.20$ & Menuju batu belimbing \\
\hline 15. $16.20-16.35$ & Batu belimbing \\
\hline 16. $16.35-17.00$ & Coffee break di Batu Kapur \\
\hline 17. $17.00-18.00$ & Sunset Batu Kapur \\
\hline 18. $18.00-18.10$ & Menuju resto lokal \\
\hline 19. $18.10-19.10$ & Makan malam \\
\hline 20.19 .10 & C/i hotel/homestay (free program \\
\hline
\end{tabular}

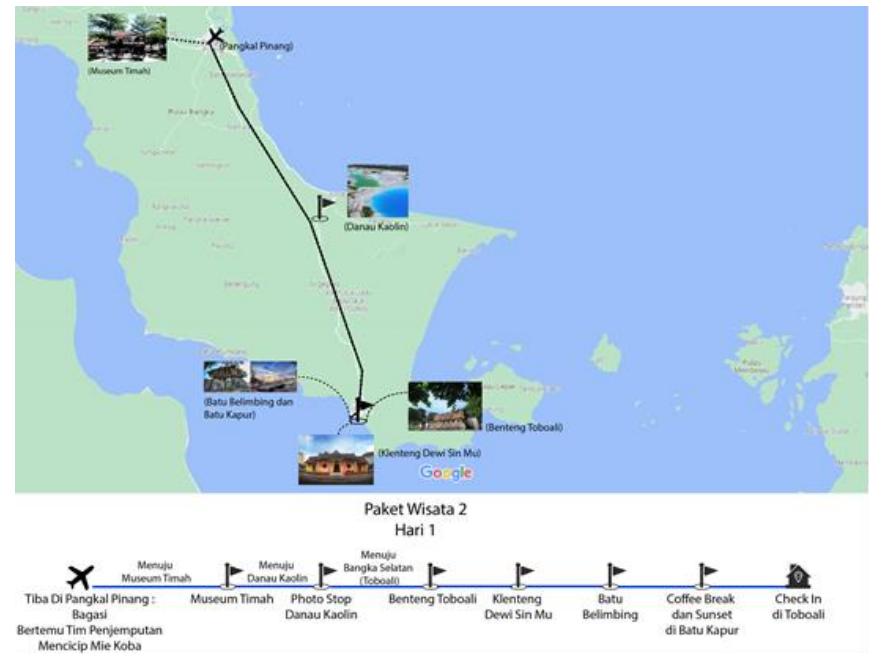

Tabel 6. Paket Wisata 2 - Bangka Energic Underwater - Hari Kedua

\begin{tabular}{lll}
\hline No & Waktu & \multicolumn{1}{c}{ Acara } \\
\hline 1. & 06.00 & C/o hotel/homestay di toboali \\
\hline 2. & $06.30-06.45$ & Persiapan menuju kelapan \\
\hline 3. & $06.45-08.15$ & $\begin{array}{l}\text { Makan pagi di kapal (nasi uduk } \\
\text { + sanck box) }\end{array}$ \\
\hline 4. & $08.15-10.15$ & $\begin{array}{l}\text { Tiba di spot snorkeling, } \\
\text { aktifitas snorkling/diving yang } \\
\text { didampingi oleh pemandu lokal }\end{array}$ \\
\hline 5. & $10.15-12.15$ & Menuju pulau tinggi \\
\hline 6. & $12.15-13.45$ & $\begin{array}{l}\text { Bilas dan makan siang di } \\
\text { keramba apung }\end{array}$ \\
\hline 7. & $13.45-14.15$ & Menuju pelabuhan sadai \\
\hline 8. & $14.15-16.45$ & Menuju kota pangkalpinang \\
\hline 9. & $16.45-17.45$ & $\begin{array}{l}\text { Kuliner martabak dan sunset di } \\
\text { jembatan emas }\end{array}$ \\
\hline 10. & $17.45-18.00$ & Menuju resto aroma laut \\
\hline 11. & $18.00-19.00$ & Makan malam di aroma laut \\
\hline 12. & 19.00 & $\begin{array}{l}\text { C/i hotel di pangkalpinang } \\
\text { (free program) }\end{array}$ \\
\hline
\end{tabular}

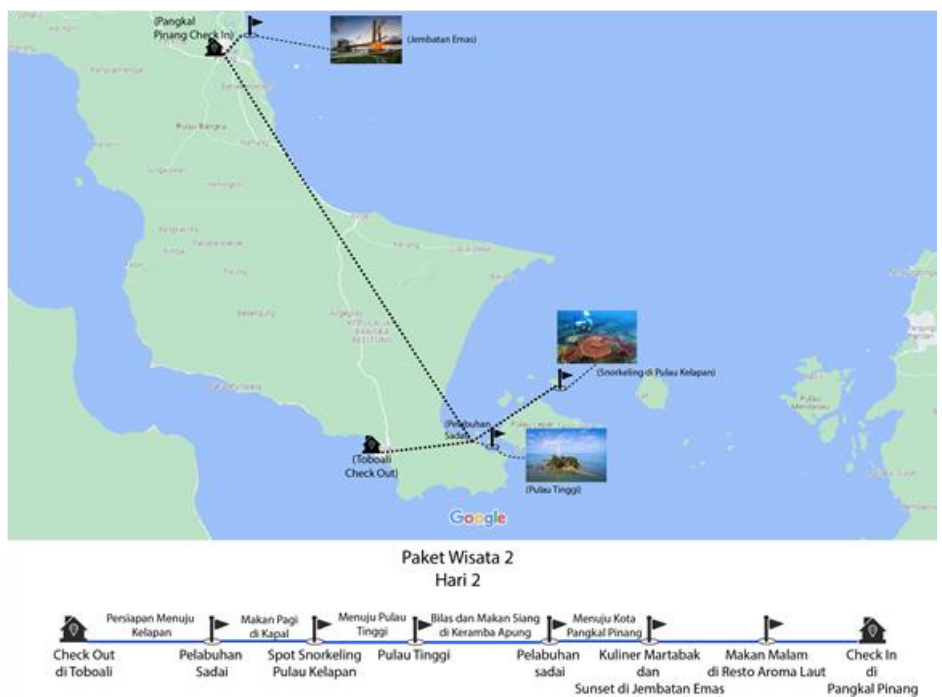


Tabel 6. Paket Wisata 2 - Bangka Energic Underwater - Hari Ketiga

\begin{tabular}{lll}
\hline No & Waktu & \multicolumn{1}{c}{ Acara } \\
\hline 1. & $06.00-08.00$ & C/o dan sarapan di hotel \\
\hline 2. & $08.00-08.45$ & Belanja oleh-oleh \\
\hline 3. & $08.45-09.30$ & Makan otak-otak ase \\
\hline 4. & $09.30-10.00$ & Es campur ayong (optional) \\
\hline 5. & $10.00-11.00$ & Perjalanan sungailiat \\
\hline 6. & $11.00-11.45$ & Puri tri agung \\
\hline 7. & $11.45-12.30$ & Pantai tikus emas \\
\hline 8. & $12.30-13.30$ & Makan siang raja laut \\
\hline 9. & $13.30-14.30$ & Airport dari sungailiat \\
\hline
\end{tabular}

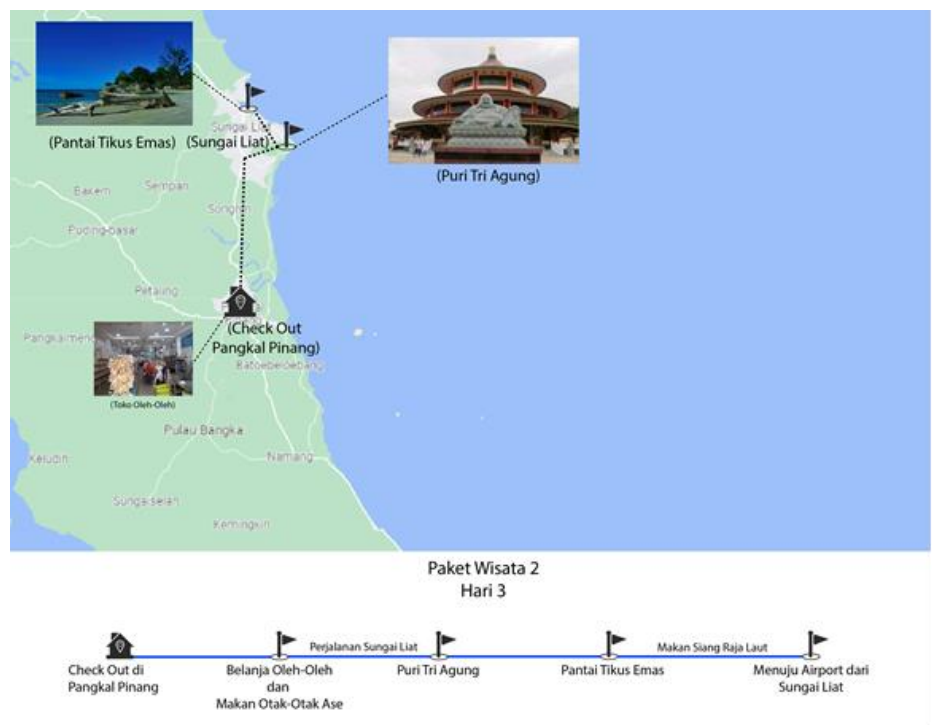

Paket Wisata 2 'Bangka Energic Underwater' ini membawa wisatawan menjelajah kekayaan alam bawah laut yang ada di Kabupaten Bangka Selatan, mulai dari Toboali, Batu Kapur, Pulau Kelapan, hingga Pulau Tinggi. Keindahan alam tersebut dinikmati dengan kegiatan snorkeling dan diving. Sebagai pelengkap, wisatawan juga diajak menelusuri Kota Pangkalpinang dan Sungailiat untuk melengkapi pengalamannya menikmati wisata di Pulau Bangka.

Sebagai catatan tambahan, 2 paket wisata di atas sudah berusaha menampilkan potensi dan daya tarik wisata yang ada di Bangka Selatan maupun area sekitar Kota Pangkalpinang, namun dalam penyusunan itinerary-nya masih terkesan sangat padat. Ada baiknya apabila agenda yang padat tersebut dipecah menjadi beberapa paket wisata lagi agar lebih longgar waktunya.

Penyusunan paket wisata sebaiknya disertai dengan penentuan pola perjalanan untuk menyusun peta jelajah wisatanya. Hal ini cukup penting, karena peta jelajah akan bisa dimanfaatkan sekaligus sebagai sarana promosi wisata yang ada di wilayah tersebut (Fatimah \& Ariaji, 2018). Untuk selanjutnya, pengembangan pariwisata diharapkan bisa mencakup 4 hal berikut sebagai visi ke depannya, yakni: 1) meningkatkan kepuasan wisatawan, 2) mengembangkan ekonomi dan keberhasilan usaha, 3) pemanfaatakan sumber daya yang berkelanjutan, 4) intergrasi antara masyarakat dan Kawasan (Gunn \& Turgut, 2002).

\section{KESIMPULAN DAN SARAN}

\section{Kesimpulan}

Kabupaten Bangka Selatan memiliki potensi wisata yang cukup lengkap mulai dari wisata alam, budaya, sejarah, perbukitan, pantai, hingga jelajah pulau. Posisinya yang berada di ujung selatan Pulau Bangka dan meliputi beberapa pulau kecil, menjadikan potensi pantai dan kekayaan alam bawah laut menjadi daya tarik tersendiri. Namun, selama ini pariwisata di Bangka Selatan belum begitu berkembang seperti daerah lainnya, antara lain karena jaraknya yang cukup jauh dari pusat kota Pangkalpinang, hingga aksesibilitasnya yang cukup rendah. Dengan penyusunan paket wisata ini diharapkan memudahkan wisatawan yang akan menikmati wisata Bangka Selatan, karena kegiatannya sudah terprogram, sehingga lebih praktis. Dua paket wisata yang disusun mencoba menawarkan potensi utama menikmati daerah pantai dan pulau-pulau kecil di wilayah Bangka Selatan, dipadukan dengan kunjungan ke berbagai titik potensi lainnya seperti wisata budaya, sejarah, serta kuliner. 


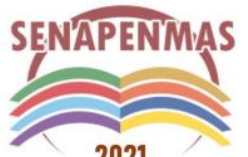

2021
Seminar Nasional Hasil Penelitian dan Pengabdian Kepada Masyarakat 2021

Pengembangan Ekonomi Bangsa Melalui Inovasi Digital Hasil Penelitian dan Pengabdian Kepada Masyarakat Jakarta, 21 Oktober 2021

\section{Saran}

Untuk penyempurnaan paket wisata yang sudah disusun, perlu dipertimbangkan alokasi waktunya dalam penyusunan agenda kegiatan sehingga tidak terkesan padat dan melelahkan.

\section{Ucapan Terima Kasih (Acknowledgement)}

Kegiatan pengabdian kepada masyarakat kali ini adalah kegiatan kerjasama antara Asisten Deputi Pengembangan Wisata Budaya, Deputi Bidang Pengembangan Destinasi Pariwisata Kementerian Pariwisata RI, serta Dinas Pariwisata Provinsi Kepulauan Bangka Belitung dan Dinas Pariwisata Kabupaten Bangka Selatan. Terima kasih kami ucapkan kepada Tim Percepatan Pengembangan Wisata Sejarah Religi Tradisi dan Seni Budaya yang sudah memfasilitasi kami melaksanakan kegiatan ini.

\section{REFERENSI}

Badan Pusat Statistik Kabupaten Bangka Selatan (2021) Statistik Daerah Kabupaten Bangka Selatan 2021, URL: https://bangkaselatankab.bps.go.id/

BAPPEDA Provinsi Kepulauan Bangka Belitung. (2013). Kajian Strategi Pengembangan Destinasi Unggulan dan Desa Wisata di Provinsi Kepulauan Bangka Belitung Laporan Draft Akhir 2013

Fatimah, T. \& Ariaji, P.E., (2018). Pembuatan Peta Jelajah Pusaka Desa Giritengah, Borobudur sebagai Sarana Informasi dan Promosi Wisata, Seminar Nasional PKM UPN Veteran Jakarta, 1(1)

Fatimah, T, Wahyuningputri, R.A., \& Hasudungan, R.T. (2020). Pemanfaatan Potensi Sejarah dan Budaya untuk Produk Wisata Berkelanjutan di Kabupaten Semarang, Jurnal Bakti Masyarakat Indonesia, 3(2), 456-465

Fatimah, T. et. al., (2018). Pemetaan Budaya Di Kawasan Pedesaan: Studi Kasus Desa Giritengah, Borobudur Jurnal Muara Sains, Teknologi, Kedokteran dan Ilmu Kesehatan, 2(2), 562-571 doi: 10.24912/jmstkik.v2i2.3008

Gunn, C. A, \& Turgut, V. (2002). Tourism Planning: Basic Concept Cases. New York: Routledge.

Humphreys, C. \& Holloway, J. C. (2016). The Business of Tourism, $10^{\text {th }}$ Edition. University of Westminster: Pearson

Kurniawan, F., dkk. (2016). Vulnerability assessment of small islands to tourism: The case of the Marine Tourism Park of the Gili Matra Islands, Indonesia. Global Ecology and Conservation 6, 308-326.

Megawandi, Y. (2020). Pembangunan Pariwisata di Provinsi Kepulauan Bangka Belitung dalam Pendekatan Whole of Government. Jurnal Widyaiswara Indonesia 1(2), 108-119.

Nasrullah, F. (2021). Pariwisata Kabupaten Bangka Selatan Potensi Asli Daerah yang Tertidur, URL: $\quad$ https://negerilaskarpelangi.com/2021/07/02/pariwisata-kabupaten-bangka-selatanpotensi-pendapatan-asli-daerah-yang-tertidur/, diakses tanggal 9 September 2021

Nuriata. (2014). Paket Wisata, Penyusunan Produk dan Penghitungan Harga. Bandung: Alfabeta

Peraturan Daerah Provinsi Kepulauan Bangka Belitung Nomor 14 Tahun 2017 Tentang Rencana Pembangunan Jangka Menengah Daerah (RPJMD) Perubahan Provinsi Kepulauan Bangka Belitung Tahun 2012-2017.

Peraturan Daerah Nomor 12 Tahun 2016 tentang Rencana Pembangunan Jangka Menengah Daerah (RPJMD) Kabupaten Bangka Selatan Tahun 2016-2021

Peraturan Daerah Nomor 6 Tahun 2012 tentang Rencana Pembangunan Jangka Panjang Daerah (RPJPD) Kabupaten Bangka Selatan Tahun 2005-2025, 
Peraturan Daerah Provinsi Kepulauan Bangka Belitung nomor 7 Tahun 2016 tentang Rencana Induk Pembangunan Kepariwisataan Provinsi Kepulauan Bangka Belitung Tahun 20162025.

Peraturan Daerah Nomor 17 Tahun 2007 tentang Penetapan Kawasan Wisata Bahari

Peraturan Pemerintah No. 50 Tahun 2011 Tentang Rencana Induk Pembangunan Kepariwisataan Nasional

Peraturan Pemerintah Nomor 6 tahun 2016 Tentang Kawasan Ekonomi Khusus (KEK) Tanjung Kelayang.

Prasetyo, A.S., Fatimah, T., Padawangi, R. (2017). Perkembangan Kota Lama Tangerang dan Potensinya sebagai Destinasi Wisata Pusaka, Vitruvian: Jurnal Arsitektur, Bangunan, dan Lingkungan 7(1), 17-30

Putra, N., (2018) Pemkab Basel Fokus Bangun Wilayah Pesisir Pantai dan Pulau Kecil, URL: https://negerilaskarpelangi.com/2018/03/07/pemkab-basel-fokuskan-pembangunan-diwilayahpesisir-pantai-dan-pulau-pulau-kecil/, diakses tanggal 9 September 2021

Ramadhani, B., et al. (2018). Government Cooperation: Kerjasama Pemerintah Pusat Dan Daerah Dalam Pengembangan Destinasi Prioritas Pariwisata di Tanjung Kelayang, Bangka Belitung. Universitas Muhammadiyah Malang

Rencana Tata Ruang Wilayah (RTRW) Kabupaten Bangka Selatan Tahun 2011-2031

Rencana Induk Pembangunan Kepariwisataan Provinsi (RIPPARPROV) Kepulauan Bangka Belitung 2016 - 2025

TIC Bangka Selatan (2021), Website Direktori Pariwisata Kabupaten Bangka Selatan, URL https://www.wisatabangkaselatan.com/ 